Industrial Health, 1982, 20, 157-159.

\title{
Haematological Changes in Fish Exposed to Endosulfan
}

\author{
Keywords : Hematocrit value-Hypercoagulability
}

The blood shows frequently immediate response to the changing external environment which can be measured in toxicological studies. Therefore haematological indexes in fish are promising tools for investigating physiological changes caused by pesticides ${ }^{1,2}$. Endosulfan, an insecticide of Cyclodiene group, is widely used in rice field and is extremely toxic for aquatic organisms ${ }^{35)}$. There is little information of endosulfan intoxication on the haematology of fresh water fish. Therefore the present work was undertaken to see haematological changes in a fresh water fish Clarias batrachus after exposure to sublethal doses of endosulfan.

Live Clarias batrachus (weight 45-50 g) were collected and acclimatized under standard laboratory conditions ${ }^{6}$. . The experiments were conducted in widemouthed glass containers containing twenty litres of diluent (tap water) with the following characteristics; temperature $20 \pm 2{ }^{\circ} \mathrm{C}$; $\mathrm{pH} 6.9-7.2$; dissolved oxygen $6.8-7.4 \mathrm{mg} / \mathrm{l}$; alkalinity $95-100 \mathrm{mg} / l$ and hardness $118-122 \mathrm{mg} / l$. Three groups each containing twenty fish were exposed to endosulfan for ten days at sublethal concentrations $(0.002,0.006$ and $0.01 \mathrm{ppm})$. Parallel groups of control fish were maintained under identical conditions. Technical grade (95\% purity) of endosulfan (Hoechst), dissolved in ethanol $(100 \mu \mathrm{g} / \mathrm{ml})$, was used as stock solution. Experimental media were always aerated and continuous exposure of the pesticide was maintained during the experimental period.

Blood of six fish from each group was taken out directly from the tail. The erythrocyte count (per $\mathrm{mm}^{3}$ ) was determined by Neubauer double hemocytometer (Germany) for which Hayem's solution was used as diluting fluid. The hemoglobin for $100 \mathrm{~m} l$ blood was determined by Sahli's hemometer (Germany). The hematocrit was determined with microhematocrit pipette (U.S.A.). Coagulation time(s) was determined according to method of Lee and White (1913) ${ }^{7)}$. Mean cell diameter $(\mu)$ were determined by direct measurement of erythrocytes with the help of occulometer. Absolute values viz. mean corpuscular volume (MCV), mean corpuscular hemoglobin $(\mathrm{MCH})$ and mean corpuscular hemoglobin concentration (MCHC) were determined using the standard formulae. Statistical significance of differences between observations were determined by applying t-test method.

The results of the experiment are shown in Table 1. Exposure of $0.002 \mathrm{ppm}$ endosulfan to $C$. batrachus for ten days induced significant increase in erythrocyte count, hemoglobin content $(\mathrm{p}<0.001)$ and hematocrit value $(\mathrm{p}<0.05)$. Mahajan and Juneja $(1979)^{8)}$ have also shown the similar changes in air breathing fish. Hoshina $(1964)^{9)}$ considered that loss of water from the body might be resulted 
Table 1. Effect of endosulfan on the haematological parameters of a fresh water teleost fish.

\begin{tabular}{lcccc}
\hline \multicolumn{1}{c}{ Parameter } & Control (Water) & $\begin{array}{c}\text { Experimental } \\
0.002\end{array}$ & $\begin{array}{c}\text { (Endosulfan ppm) } \\
0.006\end{array}$ & 0.01 \\
\hline $\begin{array}{l}\text { Erythrocytes } \\
\left(\times 10^{6} / \mathrm{mm}^{3}\right)\end{array}$ & $2.91 \pm 0.24$ & $4.55 \pm 0.18^{\mathrm{xxx}}$ & $2.71 \pm 0.23$ & $1.73 \pm 0.14^{\mathrm{xxx}}$ \\
$\begin{array}{l}\text { Hemoglobin } \\
\quad(\mathrm{g} / 100 \mathrm{~m} l)\end{array}$ & $13.05 \pm 0.38$ & $20.47 \pm 1.25^{\mathrm{xxx}}$ & $13.13 \pm 1.19$ & $9.13 \pm 0.48^{\mathrm{xxx}}$ \\
MCD $(\mu)$ & $12.92 \pm 0.77$ & $12.25 \pm 0.68$ & $16.08 \pm 1.0^{\mathrm{x}}$ & $18.33 \pm 0.49^{\mathrm{xxx}}$ \\
Hematocrit $(\%)$ & $68.17 \pm 2.23$ & $74.17 \pm 1.33_{\mathrm{xx}}$ & $60.33 \pm 1.73^{\mathrm{x}}$ & $49.50 \pm 0.02^{\mathrm{xxx}}$ \\
MCV $\left(\mu \mathrm{m}^{3}\right)$ & $24.20 \pm 2.13$ & $14.08 \pm 1.36^{\mathrm{xx}}$ & $22.82 \pm 1.28$ & $29.52 \pm 2.52$ \\
MCH $\left(10^{-12} \mathrm{~g}\right)$ & $4.6 \pm 0.32$ & $4.56 \pm 0.38$ & $5.05 \pm 0.69$ & $5.37 \pm 0.27$ \\
NCHC $(\%)$ & $19.21 \pm 0.63$ & $27.70 \pm 2.02^{\mathrm{xx}}$ & $21.86 \pm 2.06$ & $18.53 \pm 0.97$ \\
Coagulation Time $(\mathrm{S})$ & $114.3 \pm 0.12$ & $119.6 \pm 0.34^{\mathrm{xxx}}$ & $120.50 \pm 0.31^{\mathrm{xxx}}$ & $120.50 \pm 0.44^{\mathrm{xxx}}$ \\
\hline
\end{tabular}

All the values in the table represent the mean \pm S.E. $(N=6)$.

${ }^{\mathrm{xxx}} \mathrm{p}<0.001,{ }^{\mathrm{xx}} \mathrm{p}<0.01,{ }^{\mathrm{x}} \mathrm{p}<0.05$ (Student's t-test).

in relative increase of the erythrocyte count and hemoglobin. Significant decrease were observed in erythrocyte count, hemoglobin and hematocrit at 0.006 and $0.01 \mathrm{ppm}$ levels. Mount and Putricki $(1966)^{10)}$ noted that hematocrit values were lowered to half of the normal while investigating fish was killed due to endrin. Verma et al. (1979) ${ }^{11)}$ have also shown that several haematological parameters were found either increased or decreased as a result of chronic chlordane toxicity in fresh water teleost fish. MCV decreases $(p<0.01)$ significantly at $0.002 \mathrm{ppm}$ while $\mathrm{MCHC}$ increases $(\mathrm{p}<0.01)$ at the same concentration. $\mathrm{MCH}$ and MCHC were not altered significantly following exposure of 0.006 and 0.01 $\mathrm{ppm}$ of endosulfan. The mean cell diameter indicated swelling pattern at each higher sublethal dose. Misra et al. (1981) ${ }^{12}$ ) have shown that endosulfan gets entry into the cell by interacting with the membrane of high density lipoprotein and thereby causing hemolysis in cat blood. Significant increase $(p<0.001)$ in coagulation time is a deleterious effect of endosulfan on fish blood hypercoagulability.

Endosulfan is consisted of two isomeric forms of $\alpha$ and $\beta$, and the latter is highly soluble in soil and other media. The chemical nature and solubility of the metabolite makes endosulfan more potentially toxic to fish and other aquatic organisms. It is concluded that haematological parameters may be used for rapid evaluation of endosulfan toxicity for fish added to the aquatic environment.

\section{REFERENCES}

1) Metelev, V.V. (1976). Tr. Vses. Nauch. Issled. Inst. Vet. Sanit. 43, 227.

2) Gopal, K., Khanna, R.N., Anand, M. and Gupta, G.S.D. (1980). Indian. J. Biochem. Biophys. 17 (4), S III.

3) Reddy, T., Gopal, K. and Comathy, S. (1977). Indian. J. Environ. Hlth. 19, 360.

4) Gopal,K., Khanna, R.N., Anand, M. and Gupta, G.S.D. (1981). Toxicol. Lett. 7, 453. 
5) Schottger, R.A. (1976). Invest. Fish. Contr. 35, 31.

6) Franson, M.A. (1975). Standard methods for the examination of water and waste water, p. 689, 1015. Eighteenth street N.W. Washington.

7) Lee, R.I. and White, P.D. (1913). Amer. J. Med. Sci. 145, 495.

8) Mahajan, C.L. and Juneja, C.J. (1979). Indian. J. Environ. Hlth. 21, 162.

9) Hoshina, T. (1964). Jour. Tokyo. Univ Fish. 6, 1.

10) Mount, D.I. and Putricki, G.J. (1966). Trans. 31st. N. Amer. Wildl. Conf. 177.

11) Verma S.R., Bansal, S.K., Gupta, A.K. and Dalela, R.C. (1979). Bull. Environ. Contam. Toxicol. 22, 467.

12) Misra, D., Khanna, R.N., Anand, M. and Gopal, K. (1981). J. Adv. Zool, (In press).

Industrial Toxicology Research Centre, Post Box No. 80, M.G. Marg, Lucknow (India)-226001.
Krishna GOPAL, R.N. KHANNA, M. ANAND and G.S.D. GUPTA.

(Received October 2, 1981 and in revised form March 11, 1982) 